\title{
Impact of Natural and Synthetic Plant Stimulants on Moringa Seedlings Grown under Low-Temperature Conditions
}

\section{Sumaira Batool ${ }^{1}$, Shahbaz Khan ${ }^{2 *}$, Shahzad MA Basra ${ }^{3}$, Mumtaz Hussain ${ }^{1}$, Muhammad Sohail Saddiq ${ }^{2}$, Shahid Iqbal ${ }^{4}$, Sohail Irshad ${ }^{5}$, Saqib Bashir ${ }^{6}$, Muhammad Bilal Hafeez ${ }^{3}$}

${ }^{1}$ Department of Botany, University of Agriculture, Faisalabad (38040), Pakistan

${ }^{2}$ Department of Agronomy, Ghazi University, Dera Ghazi Khan (32200), Pakistan

${ }^{3}$ Department of Agronomy, University of Agriculture, Faisalabad (38040), Pakistan

${ }^{4}$ Department of Agronomy, Muhammad Nawaz Shareef, University of Agriculture Multan, Pakistan

${ }^{5}$ Agricultural Training Institute, Rahim Yar Khan, Pakistan

${ }^{6}$ Department of Soil and Environmental Science, Ghazi University, Dera Ghazi Khan (32200), Pakistan

*Corresponding author’s email: shahbaz2255@gmail.com; shkhan@gudgk.edu.pk

Keywords: Foliar MLE, seedlings, temperature, phenolic compounds, growth.

Abstract. Low-temperature results in various physiological and metabolic disturbances in cells of plants which are sensitive to low-temperatures. Moringa is getting popularity as a field crop because of its multipurpose usage. There is no information available about effects of low-temperature (14$18^{\circ} \mathrm{C}$ ) on moringa seedlings and its mitigation. The present study was conducted to test the performance of moringa seedling grown in wire house under low-temperature conditions in response to foliar application of moringa leaf extract ( $3 \%$ solution), hydrogen peroxide $\left(5 \mathrm{ml} \mathrm{L}^{-1}\right)$, ascorbic acid $\left(50 \mathrm{mg} \mathrm{L}^{-1}\right)$ and salicylic acid $\left(50 \mathrm{mg} \mathrm{L}^{-1}\right)$. Seeds of six moringa accessions [Local landrace grown at Agronomic Research Area, Z.A Hashmi Hall, Firdous Colony; Exotic landrace grown at Lalazaar Colony, Department of Agronomy and Agronomic Research Area] were collected and grown in polythene bags filled with equal ratio of compost, sand, silt and clay. All foliar treatments were applied twice; the first round at the seedling age one month and the second round at the seedling age two months. Foliar application of moringa leaf extract significantly enhanced number of branches (92\%) and leaves (39\%), leaf total chlorophyll contents (73\%), leaf phenolic contents $(53 \%)$ and membrane stability index $(57 \%)$ of moringa seedlings compared to control. Healthy and vigorous growth of moringa seedlings with higher concentration of antioxidants ensured the defensive potential of moringa leaf extract against low-temperature condition.

\section{Introduction}

Moringa oleifera tree is referred to as a miracle tree because of rich source certain macro and micronutrients of great importance in human nutrition [1], agriculture [2] and pharmacology [3]. Moringa oleifera Lam., the main representative of the order Moringa, is native to Hamaylian track of Indo-Pak [4] with three landrace i.e. white seeded moringa, black seeded moringa and PKM1, present in Pakistan [5]. It belongs to family Moringaceae and it is also commonly known as horse radish tree or drum stick. Moringa has both medicinal and nutritional values and uses with essential minerals, amino acids and vitamins [6]. It is also commonly grown on plantations in Asia and Africa. Almost all plant part of this miracle tree have been found to be very useful and edible as they contain a multitude of nutrients such as high level of essential amino acids, iron calcium and carotenoids [7]. It can be cultivated in different ways, but more often the tree is cultivated intensively in plantations to harvest large volume of leaf material $[8,9]$. 
Low-temperature is one of main important plants abiotic stress issues which curtail plant growth, development and yield. Accumulation or synthesis of compatible metabolites is a fundamental and useful strategy for the survival of plant in metabolic acclimation. A prominent object of metabolic analysis with respect to chilling stress of cold acclimation condition is to recognize the metabolites which are frequently involved in homeostasis and maintaining the optimum and normal cellular metabolism [10]. Exogenous application of plant growth regulators (PGRs) with specific mineral nutrients, organic and inorganic chemicals and antioxidants has been successfully used to encourage crop development and growth and inducing biotic and abiotic stresses tolerance that outcomes in more economic yield [11, 12]. Natural sources like microorganisms and/or organic compounds are also being used as biostimulant in agriculture. Most commonly used biostimulants are microbial inoculants, seaweed extracts, humic acids, fulvic acids, plant extracts, protein hydrolysates and amino acids [13]. Moringa leaf extract obtained from fresh leaves of moringa possesses high antioxidant activity as it is rich in some plant secondary metabolites and osmoprotectants [14]. Moringa leaves are natural and economical source of calcium, iron, vitamin A and C, beta-carotene, phenolics and riboflavin [15]. The potential of MLE when applied as either seed priming agent or plant foliage has been exposed to increase the plant tolerance to abiotic stresses [16].

Phenolic compounds present in moringa plant could prevent chronic non-communicable diseases. An increase in the secondary metabolites of Moringa oleifera could improve its functional properties [17]. Siddhuraju and Becker [18] observed antioxidant properties in the solvent extract of moringa leaves. Moreover, moringa leaf extract is supplemented with zeatin, a purine adenine derivative of plant hormone group cytokinin [19] known for stay green and stress tolerance competences. Salicylic acid, a plant phenolic PGR of ubiquitous nature, plays a key role in the plant response to unfavorable environment [20]. Ascorbic acid and related enzymes like ascorbate peroxidase (APX) play various roles in physiological process in plants, including differentiation, growth, metabolism and expansion [21]. Furthermore, ascorbate regenerate $\alpha$-tocopherol which defend the plant from programmed cell death, oxidized by ROS [22]. Hydrogen peroxide $\left(\mathrm{H}_{2} \mathrm{O}_{2}\right)$ has numerous roles as a plant signaling molecule, secondary messenger, mediating the acquisition of tolerance to abiotic stress [23].

The beneficial effects of hydrogen peroxide, salicylic acid and ascorbic acid in comparison with moringa leaf extract to enhance the growth of moringa seedling under-low temperature have not been reported. It is evident from earlier mentioned reports that moringa leaf extract preserves antioxidants in significant amounts but very slight published literature is available about effectiveness of moringa leaf extract under low-temperature stress regarding moringa seedlings. In view of all these reports, it is hypothesized that leaf extract from moringa, having a number of plant growth promoters, mineral nutrients and vitamins in a naturally balanced composition, may be beneficial for growth and development of moringa seedlings under low-temperature environment. Therefore, the present study was conducted to investigate the performance of moringa seedling under low temperature in response to foliar application of moringa leaf extract, salicylic acid, hydrogen peroxide and ascorbic acid.

\section{Materials and Methods}

\section{Experiment particulars}

The current study was planned to explore the defensive potential of moringa leaf extract (MLE), salicylic acid, hydrogen peroxide and ascorbic acid against low-temperature stress through the performance of moringa seedlings of different landraces. Two most prominent landraces i.e. local landrace (LL) (a white seeded moringa) and an exotic landrace (EL) (PKM1; Indian cultivar), were selected for current experimentation. Seeds of three accessions of local landrace were collected from Agronomic Research Area (LL1), Z.A Hashmi Hall (LL2) and Firdous Colony (LL3). Similarly, seeds of three accessions of PKM1 were collected from Lalazaar Colony (EL1), 
Department of Agronomy (EL2) and Agronomic Research Area (EL3), University of Agriculture Faisalabad, Pakistan.

\section{Seedlings growth and treatments}

Seedlings were grown in polythene bags under wire house at Old Botanical Garden, Department of Botany, University of Agriculture, Faisalabad-Pakistan in winter season (November 2016 to February 2017) with average temperature of $14-18^{\circ} \mathrm{C}$. Normally, moringa is cultivated during summer season because moringa is a plant of tropical and sub-tropical region with average temperature of $25-35^{\circ} \mathrm{C}$ [24]. Cultivation of moringa seedlings under natural winter season is considered as low temperature. Weather data are given in table 1. Five seeds from each accession were sown in polythene bags. Polythene bags $(18 \mathrm{~cm}$ length and $10 \mathrm{~cm}$ width) were filled with growing media. Growing media consist of compost, sand, silt and clay with equal ratio. Completely randomized design (CRD) with factorial arrangements having three replications was used to conduct the experiment. Foliar spray of water, salicylic acid@50 mg L-1, hydrogen peroxide (a) $50 \mathrm{ml} \mathrm{L}^{-1}$, ascorbic acid @ $50 \mathrm{mg} \mathrm{L}^{-1}$ and moringa leaf extract @ 3\% [5] was applied on the seedling which were later compared with control seedlings which received no exogenous treatment. Moringa leaf extract was prepared according to Khan [5]. The volume of spray for each plant was $40 \mathrm{ml}$. During course of experimentation, all foliar treatments were applied twice; first round at the seedling age one month and second round at the seedling age of two months.

\section{Seedling growth and biochemical analysis}

Data of growth parameters like number of branches per seedling, number of compound leaves per seedling and number of leaflets per compound leaf were recorded after one week of foliar treatment application of the second round. Chlorophyll of moringa seedlings were determined according to Arnon [25].

$$
\begin{aligned}
& \text { Chlorophyll } a\left(\mathbf{m g ~ g}^{-1}\right)=[\{(0.0127 \times \mathrm{A} 663)-(0.00269 \times \mathrm{A} 645)\} \times 100] / 0.5, \\
& \text { Chlorophyll } \boldsymbol{b}\left(\mathbf{m g ~ g}^{-1}\right)=[\{(0.0229 \times \mathrm{A} 645)-(0.00468 \times \mathrm{A} 663)\} \times 100] / 0.5 .
\end{aligned}
$$

Total phenolic contents in leaf samples were measured by using a method as described by Ainsworth and Gillespie [26]. Leaf Membrane Stability Index (MSI) was determined according to the method of by Sairam [27]. MSI was calculated using the following formula;

$$
\mathrm{MSI}=\left[1-\left(\mathrm{C}_{1} / \mathrm{C}_{2}\right)\right] \times 100 \text {. }
$$

\section{Statistical analysis}

The collected data were analyzed statistically by employing the Fisher's analysis of variance technique [28] and treatments' means were compared by using Tucky HSD test at 5\% probability level. Computer package Statistix 8.1 was used for statistical analysis (Analytical Software, Tallahassee, TN, USA).

\section{Results}

\section{Growth parameters of moringa seedlings}

Foliar application of moringa leaf extract@3\% solution, salicylic acid@ 90 mg L $\mathrm{L}^{-1}$, hydrogen peroxide@ $950 \mathrm{ml} \mathrm{L}^{-1}$ and ascorbic acid@50 mg L-1 significantly improved growth attributes (i.e. number of branches per seedling, number of compound leaves per seedling and number of leaflets per compound leaf) of moringa seedlings grown under low temperature conditions as compared to control (Table 2). The number of branches and compound leaves per seedling, and number of leaflets per compound leaf were not affected within landraces and accessions but only affected by foliar application (Table 2). All the foliar treatments enhanced the number of branches and compound leaves per seedling, and number of leaflets per compound leaf over control but maximum improvement was recorded by application of moringa leaf extract (Table 3). Foliar application of moringa leaf extract produced maximum branches, compounds leaves and leaflets per 
seedling over control. The number of branches was also statistically at par with application of ascorbic acid and hydrogen per oxide. The number of leaves and leaflets were also statistically at par with ascorbic acid, hydrogen per oxide and salicylic acid.

\section{Biochemical parameters of moringa seedlings}

Foliar application of moringa leaf extract@3\% solution, salicylic acid@50 mg L $\mathrm{L}^{-1}$, hydrogen peroxide@50 ml L $\mathrm{m}^{-1}$ and ascorbic acid@50 $\mathrm{mg} \mathrm{L}^{-1}$ significantly improved biochemical attributes (i.e. Chlorophyll $a, b$ and total leaf chlorophyll contents, total leaf phenolic contents and membrane stability index) of moringa seedlings grown under low-temperature conditions as compared to control (Table 2). Leaf chlorophyll $a$ and $b$ contents and total leaf phenolics (Fig. 2a) were found similar in the landraces and accessions but total leaf chlorophyll contents were found significantly different (Table 2, Fig. 1a, b). Chlorophyll $a$ contents were also statistically at par with ascorbic acid, hydrogen per oxide and salicylic acid. Cell membrane stability index was also recorded significant among the accessions (Table 3, Fig. 2b). Foliar application of moringa leaf extract produced more leaf chlorophyll and phenolic contents over control. Interaction among landraces, accession and treatments regarding chlorophyll $a$ contents, total chlorophyll and total phenolics was also significant (Table 3) as expressed in Fig. 1a, b and 2a respectively. Maximum cell membrane stability index was recorded by application of moringa leaf extract as foliar spray over control (Table 3).

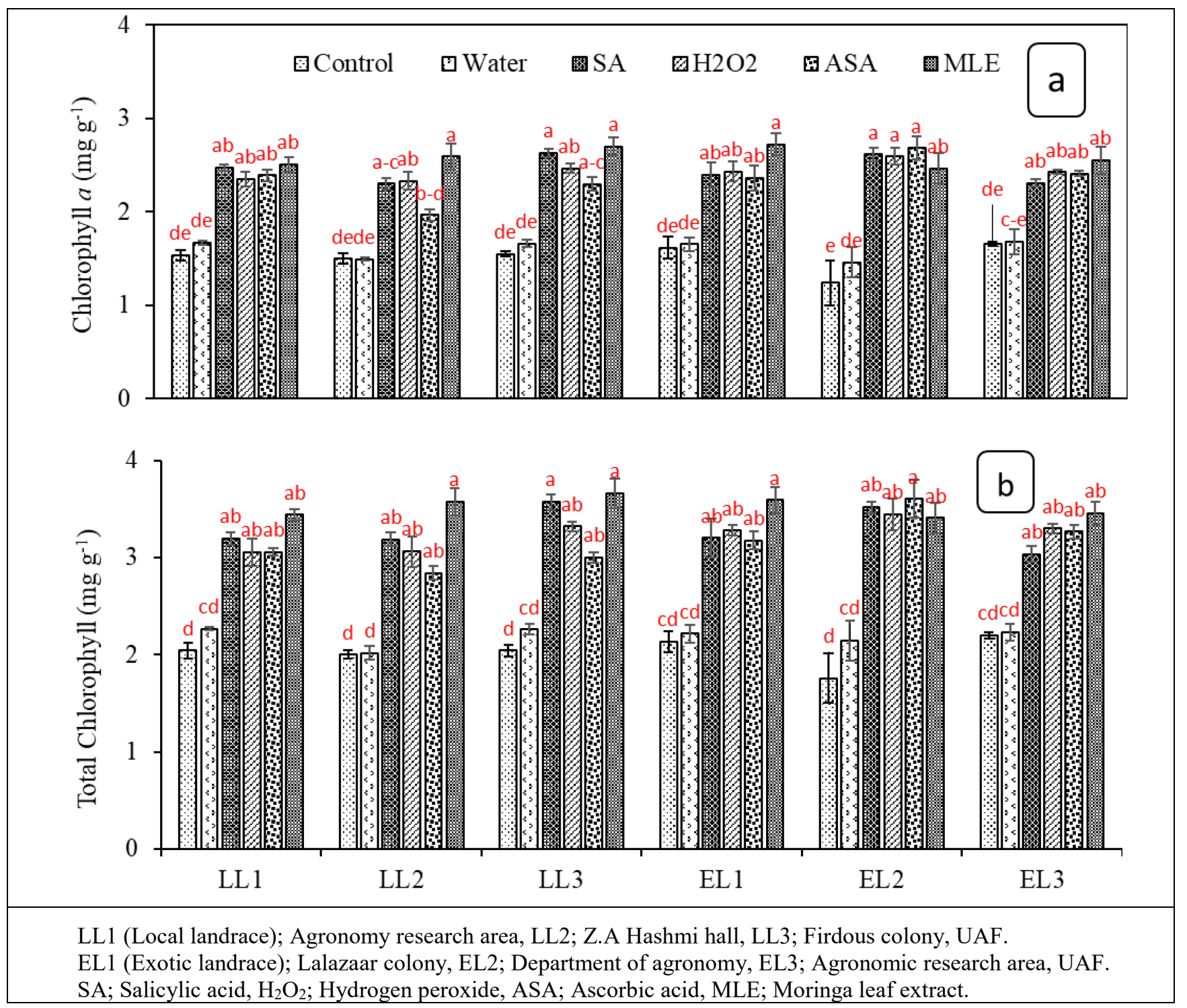

Figure 1. Leaf chlorophyll $a$ (a) and total chlorophyll contents (b) of moringa seedlings under lowtemperature stress in response to foliar application of growth promoting substance 

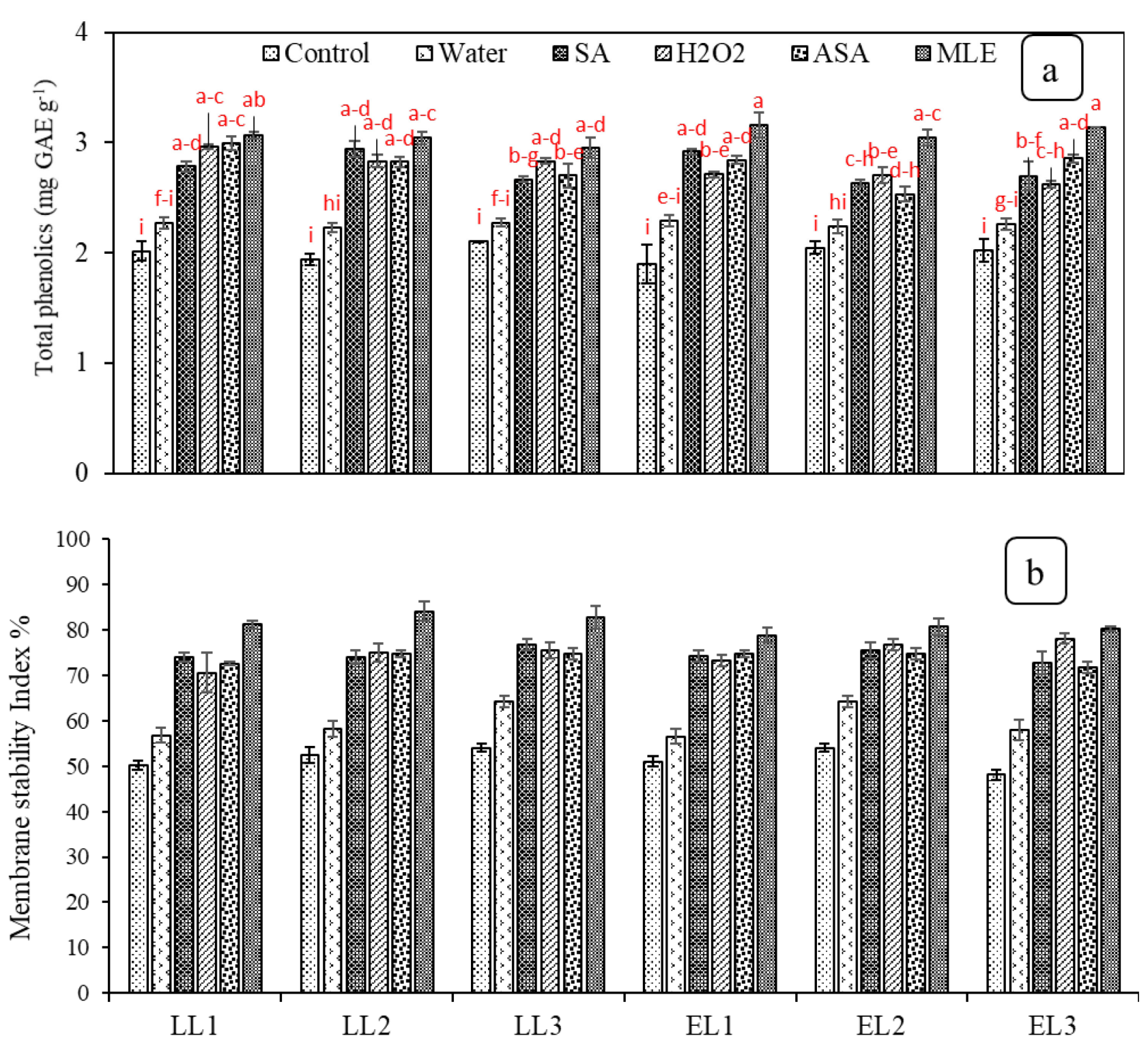

LL1 (Local moringa); Agronomy research area, LL2; Z.A Hashmi hall, L13; Firdous colony, UAF.

EL1 (Indian cultivar); Lalazaar colony, EL2; Department of agronomy, EL3; Agronomic research area, UAF.

SA; Salicylic acid, $\mathrm{H}_{2} \mathrm{O}_{2}$; Hydrogen peroxide, ASA; Ascorbic acid, MLE; Moringa leaf extract.

Figure 2. Total leaf phenolic contents (a) and membrane stability index (b) of moringa seedlings under low-temperature stress in response to foliar application of growth promoting substance

Table 1. Average monthly weather conditions during the seedling growth period

\begin{tabular}{|l|c|c|c|c|}
\hline Weather conditions & Nov-2016 & Dec-2016 & Jan-2017 & Feb-2017 \\
\hline Mean temperature $\left({ }^{\circ} \mathrm{C}\right)$ & 20.1 & 16.4 & 12.9 & 16.8 \\
\hline $\begin{array}{l}\text { Mean relative humidity } \\
(\%)\end{array}$ & 60.1 & 68.7 & 72.0 & 53.0 \\
\hline Total rainfall $(\mathrm{mm})$ & 0.00 & 0.00 & 11.5 & 4.10 \\
\hline Sun shine hours & 6.40 & 6.70 & 1.30 & 6.60 \\
\hline $\begin{array}{l}\text { Evapotranspiration } \\
(\mathrm{mm})\end{array}$ & 1.80 & 1.70 & 0.90 & 1.90 \\
\hline Wind speed $\left(\mathrm{km} \mathrm{hr}^{-1}\right)$ & 2.60 & 2.80 & 3.50 & 4.00 \\
\hline
\end{tabular}


Table 2. Mean sum of squares of growth and biochemical parameters of moringa seedlings in response to foliar application of moringa leaf extract, salicylic acid, hydrogen peroxide and ascorbic acid

\begin{tabular}{|l|c|c|c|c|c|c|c|c|c|}
\hline \multicolumn{1}{|c|}{ SOV } & DF & $\begin{array}{c}\text { No of } \\
\text { Branches }\end{array}$ & $\begin{array}{c}\text { No of } \\
\text { Leaves }\end{array}$ & $\begin{array}{c}\text { No of } \\
\text { Leaflets }\end{array}$ & $\begin{array}{c}\text { Chlorophyll Chlorophyll } \\
a\end{array}$ & $\begin{array}{c}\text { Total } \\
\text { Chlorophyll }\end{array}$ & $\begin{array}{c}\text { Total } \\
\text { Phenolics }\end{array}$ & $\begin{array}{c}\text { Membrane } \\
\text { Stability } \\
\text { Index }\end{array}$ \\
\hline $\begin{array}{l}\text { Landraces } \\
(\mathrm{L})\end{array}$ & 1 & $0.6379^{\mathrm{NS}}$ & $0.9259^{\mathrm{NS}}$ & $2.725^{\mathrm{NS}}$ & $0.0618^{\mathrm{NS}}$ & $0.0218^{\mathrm{NS}}$ & $0.157^{* *}$ & $0.0542^{\mathrm{NS}}$ & $5.15^{\mathrm{NS}}$ \\
\hline $\begin{array}{l}\text { Accessions } \\
(\mathrm{A})\end{array}$ & 2 & $6.5348^{\mathrm{NS}}$ & $8.7870^{\mathrm{NS}}$ & $1.815^{\mathrm{NS}}$ & $0.0866^{\mathrm{NS}}$ & $0.0384^{\mathrm{NS}}$ & $0.0456^{\mathrm{NS}}$ & $0.0609^{\mathrm{NS}}$ & $62.24^{* *}$ \\
\hline $\mathrm{L} \times \mathrm{A}$ & 2 & $10.164^{\mathrm{NS}}$ & $14.45^{\mathrm{NS}}$ & $8.037^{\mathrm{NS}}$ & $0.0801^{\mathrm{NS}}$ & $0.0141^{\mathrm{NS}}$ & $0.1529^{\mathrm{NS}}$ & $0.029^{\mathrm{NS}}$ & $50.16^{* *}$ \\
\hline $\begin{array}{l}\text { Treatments } \\
(\mathrm{T})\end{array}$ & 5 & $9.873^{* *}$ & $11.92^{* *}$ & $17.49^{* *}$ & $3.988^{* *}$ & $0.465^{* *}$ & $7.139^{* *}$ & $2.823^{* *}$ & $2255^{* *}$ \\
\hline $\mathrm{L} \times \mathrm{T}$ & 5 & $0.5931^{\mathrm{NS}}$ & $0.6815^{\mathrm{NS}}$ & $0.6981^{\mathrm{NS}}$ & $0.062^{\mathrm{NS}}$ & $0.021^{\mathrm{NS}}$ & $0.1433^{*}$ & $0.0432^{*}$ & $12.46^{\mathrm{NS}}$ \\
\hline $\mathrm{A} \times \mathrm{T}$ & 10 & $0.6147^{\mathrm{NS}}$ & $0.8204^{\mathrm{NS}}$ & $0.837^{\mathrm{NS}}$ & $0.0234^{\mathrm{NS}}$ & $0.0097^{\mathrm{NS}}$ & $0.0411^{\mathrm{NS}}$ & $0.0235^{\mathrm{NS}}$ & $8.63^{\mathrm{NS}}$ \\
\hline $\mathrm{L} \times \mathrm{A} \times \mathrm{T}$ & 10 & $0.3517^{\mathrm{NS}}$ & $0.4426^{\mathrm{NS}}$ & $0.5037^{\mathrm{NS}}$ & $0.093^{* *}$ & $0.0114^{\mathrm{NS}}$ & $0.1017^{*}$ & $0.0344^{*}$ & $11.45^{\mathrm{NS}}$ \\
\hline
\end{tabular}

$\mathrm{SOV}=$ Source of variance, $\mathrm{DF}=$ Degree of freedom, $\mathrm{NS}=$ non-significant, $*=$ Significant at $\mathrm{P} \leq 0.05, * *=$ Significant at $\mathrm{P} \leq 0.01$

Table 3. Growth and biochemical parameters of moringa seedlings under low-temperature stress in response to foliar application of growth promoting substance

\begin{tabular}{|l|c|c|c|c|c|c|c|c|}
\hline Treatments & $\begin{array}{c}\text { No of } \\
\text { Branches }\end{array}$ & $\begin{array}{c}\text { No of } \\
\text { Leaves }\end{array}$ & $\begin{array}{c}\text { No. of } \\
\text { Leaflets }\end{array}$ & $\begin{array}{c}\text { Chlorophyll } a \\
\left(\mathrm{mg} \mathrm{g}^{-1}\right)\end{array}$ & $\begin{array}{c}\text { Chlorophyll } b \\
\left(\mathrm{mg} \mathrm{g}^{-1}\right)\end{array}$ & $\begin{array}{c}\text { Total } \\
\text { Chlorophyll }\end{array}$ & $\begin{array}{c}\text { Total } \\
\text { Phenolics }\end{array}$ & MSI \\
\hline $\begin{array}{l}\text { Control } \\
\text { No spray })\end{array}$ & $3.167 \mathrm{D}$ & $6.22 \mathrm{C}$ & $4.83 \mathrm{C}$ & $1.5147 \mathrm{C}$ & $0.5131 \mathrm{C}$ & $2.0278 \mathrm{C}$ & $2.0043 \mathrm{D}$ & $51.583 \mathrm{D}$ \\
\hline $\begin{array}{l}\text { Water } \\
\text { spray }\end{array}$ & $3.72 \mathrm{CD}$ & $7.22 \mathrm{BC}$ & $5.17 \mathrm{BC}$ & $1.6021 \mathrm{C}$ & $0.5871 \mathrm{C}$ & $2.1891 \mathrm{C}$ & $2.2615 \mathrm{C}$ & $59.618 \mathrm{C}$ \\
\hline $\begin{array}{l}\text { Salicylic } \\
\text { acid }\end{array}$ & $4.72 \mathrm{BC}$ & $7.72 \mathrm{AB}$ & $6.33 \mathrm{AB}$ & $2.4530 \mathrm{AB}$ & $0.8314 \mathrm{~B}$ & $3.2844 \mathrm{~B}$ & $2.7726 \mathrm{~B}$ & $74.476 \mathrm{~B}$ \\
\hline $\begin{array}{l}\text { Hydrogen } \\
\text { peroxide }\end{array}$ & $4.83 \mathrm{ABC}$ & $7.67 \mathrm{AB}$ & $6.39 \mathrm{AB}$ & $2.4309 \mathrm{AB}$ & $0.8117 \mathrm{~B}$ & $3.2425 \mathrm{~B}$ & $2.7770 \mathrm{~B}$ & $74.797 \mathrm{~B}$ \\
\hline $\begin{array}{l}\text { Ascorbic } \\
\text { acid }\end{array}$ & $5.056 \mathrm{AB}$ & $7.94 \mathrm{AB}$ & $6.78 \mathrm{~A}$ & $2.3509 \mathrm{~B}$ & $0.8067 \mathrm{~B}$ & $3.1575 \mathrm{~B}$ & $2.7916 \mathrm{~B}$ & $73.783 \mathrm{~B}$ \\
\hline $\begin{array}{l}\text { Moringa } \\
\text { leaf extract }\end{array}$ & $6.11 \mathrm{~A}$ & $8.67 \mathrm{~A}$ & $7.44 \mathrm{~A}$ & $2.5897 \mathrm{~A}$ & $0.9315 \mathrm{~A}$ & $3.5212 \mathrm{~A}$ & $3.0669 \mathrm{~A}$ & $81.203 \mathrm{~A}$ \\
\hline $\begin{array}{l}\text { Tukey } \\
\text { HSD }\end{array}$ & 1.333 & 1.3565 & 1.3883 & 0.1805 & 0.0940 & 0.2135 & 0.1234 & 3.2343 \\
\hline
\end{tabular}

MSI $=$ Membrane stability index

\section{Discussion}

Moringa oleifera tree, usually known as miracle tree, is a well-known source of micro and macronutrients, proteins, vitamins [29]. Each part of this plant is very palatable and considered "natural nutrition of tropics" because it possesses many important metabolites e.g. quercetin, campesterol, kaempferol, sitosterol and zeatin [29, 30]. Moringa oleifera L. is native to Hamaylian track of Indo-Pak [4] with two prominent landrace i.e. local landrace (LL) (a white seeded moringa) and an exotic landrace (EL) (PKM1; Indian cultivar) present in Pakistan [5]. Its landraces and/or accessions are characterized by phenotypic difference, such as shape of leaves, plant height, production of leaf biomass and secondary metabolites [8, 31]. Two landraces, with three accessions of each, studied in this experiment showed growth (Table 3) and biochemical (Fig. 1 and 2) 
differences under similar environmental conditions in response to foliar application of salicylic acid, hydrogen peroxide, ascorbic acid and moringa leaf extract.

In the present study, application of moringa leaf extract improved growth (Table 3) and biochemical traits (Fig. 1 and 2) of moringa seedlings. This increase in traits might be due to presence of antioxidants and vitamins in the moringa leaf extract which enhanced the growth of seedlings. Similar results were reported by Taha et al. [32] that when moringa leaf extract is applied (a) 10\%, it causes an increase in plant height and number of branches as compared to control in jojoba plant. Moringa leaf extract possesses high antioxidant activity as it is rich in some plant secondary metabolites and osmoprotectants [14]. Moringa leaves are natural and economical source of calcium, iron, vitamin $\mathrm{A}$ and $\mathrm{C}$, beta-carotene, phenolics and riboflavin [15]. Current results were also supported by Nouman et al. [33] who stated that application of moringa leaf extract enhanced the number of tillers, leaf numbers and shoot vigor in Echinochloa crusgalli when applied as a priming agent.

Siddhuraju and Becker [18] observed antioxidant properties in the solvent extract of moringa leaves. On the basis of their results they reported that, moringa leaves are a potential source of natural antioxidants. According to Arabshahi et al. [34], extracts from drumstick and carrot had a higher antioxidant activity (83\% and $80 \%)$ than $\alpha$-tocopherol $(72 \%)$. Moreover, moringa leaf extract (MLE) is supplemented with zeatin, a purine adenine derivative of plant hormone group cytokinin [19] known for stay green and stress tolerance competences. Juice of moringa leaves is so rich with a lot of plant growth hormones, especially zeatin that is reported to boost up the yield of field crops in range of 10-45\%. It also contains many micronutrients in sufficient amounts and an appropriate concentration that enhance the growth and development, components of yield and yield of a vast range of field crop from oil seed to cereal crops, from tuber to forages crops and from sugar to fibrous crops [35]. Khan et al. [36] also reported that moringa leaf extract showed growth promoting potential due to presence of phenolics and ascorbic acid. They also stated that application moringa leaf extract was more effective regarding the growth, yield and biochemical attributes of wheat.

According to Taha et al. [32], maximum chlorophyll $a$ and $b$ contents were measured in the plants treated with higher concentration of moringa leaf extract@10\% in Jojoba plants as compared with control treatments. They also stated that same response was observed regarding total chlorophyll contents as in the present study (Fig. 1). Abdalla [37] investigated that foliar spray of MLE at moderate concentration (2L) exhibited the maximum quantity of photosynthetic pigments (i.e. chlorophyll $a$ contents and chlorophyll $b$ contents, and carotenoids) as compared to untreated plants which were considered as control. Furthermore, moringa leaf extract spray also positively adjust membrane stability or structure under chilling stress, that is why plants treated with moringa leaf extract in both the conditions either in the absence and presence of stress conditions had more membrane stability index. Application of MLE is responsible for the healthy metabolic condition of stressed plants which resulted in vigorous plant growth in term of enhanced total chlorophyll and total phenolic contents. It may be endorsed to that moringa leaf extract is an excellent source of amino acids, minerals, antioxidants and soluble sugars. Howladar [38] reported that twice application of moringa leaf extract, at 21 and 28 days after sowing of bean seeds, increase the membrane stability index $69.4 \%$. Reliable findings were also found by Prabhu et al. [39] and Balakumbahan and Rajamani [40] who reported that application of moringa leaf extracts @ 2\% and $4 \%$ on sacred basil and senna plants respectively. They stated that foliar spray of MLE@2\% was more effective as compared to control. Foliar application of MLE@2\% increased various growth attributes like numbers of leaves, plant height, leaf area and LAI, dry and fresh weights, number of branches, number of pods, dry pod yield and dry leaf yield as compared to control.

\section{Conclusion}

Foliar application of moringa leaf extract, when applied @ 3\% solution, is the most effective approach to maintain the growth of moringa seedlings under low-temperature conditions as it is a rich source of mineral nutrients, antioxidants, vitamins and growth hormones. The vigorous growth 
of local landrace ensures tolerant phenomenon against low-temperature conditions as compared to exotic landrace (PKM1).

\section{Conflict of Interest}

The authors declare that there is no conflict of interest.

\section{References}

[1] A.T. Oyeyinka, S.A. Oyeyinka, Moringa oleifera as a food fortificant: Recent trends and prospects, Journal of Saudi Society of Agricultural Science. 17 (2018) 127-136. doi: 10.1016/j.jssas.2016.02.002

[2] N. Foidl, N.P.S. Makkar, K. Becker, The Potential of Moringa Oleifera for Agricultural and Industrial Uses, What Dev potential Moringa Prod (2001) 1-20.

[3] C.Y.H. Djande, L.A. Piater, P.A. Steenkamp, Differential extraction of phytochemicals from the multipurpose tree, Moringa oleifera, using green extraction solvents, South African Journal of Botany. 115 (2018) 81-89. doi: 10.1016/j.sajb.2018.01.009

[4] U. Shahzad et al., Genetic diversity and population structure of Moringa oleifera, Conservation Genetics. 14 (2013) 1161-1172.

[5] S, Khan, S.M.A. Basra, I. Afzal, A. Wahid. Screening of moringa landraces for leaf extract as biostimulant in wheat, International Journal of Agriculture and Biology. 19 (2017) 999-1006.

[6] C. Ramachandran, K.V. Peter, P.K. Gopalakrishnan, Drum-stick (Moringa oleifera): a multipurpose Indian vegetable, Econ Bot 34 (1980) 276-283.

[7] P.M.P. Ferreira et al., Moringa oleifera: bioactive compounds and nutritional potential, Rev. Nutr. 21 (2008) 431-437.

[8] M.C. Palada, L.C. Chang, Suggested cultural practices for Moringa, International cooperators guide, AVRDC pub \# 03 (2003)545.

[9] T. Radovich, Farm and forestry, production and marketing profile for Moringa (Moringa oleifera), (http://www.agroforestry.net/scps/Moringa_specialty_crop.pdf) Jan 28, 2014.

[10] M. Janmohammadi, Metabolomic analysis of low temperature responses in plants, Current Opinions in Agriculture. 1 (2012) 1-6.

[11] M. Ashraf, M.R. Foolad, Roles of glycine betaine and proline in improving plant abiotic stress resistance, Environmental and Experimental Botany. 59 (2007) 206-216.

[12] M. Farooq et al., Plant drought stress: effects, mechanisms and management, Agron Sustain Dev. 29 (2009) 185-212.

[13] L.J. Fuglie, New Uses of Moringa Studied in Nicaragua, In ECHO Development Notes. biomasa@ibw.com (2001) P-68.

[14] M.A. Rady, B.C. Varma, S.M. Howladar, Common bean (Phaseolus vulgaris L.) seedlings overcome $\mathrm{NaCl}$ stress as a result of presoaking in Moringa oleifera leaf extract, Scientia Horticulturae. 162 (2013) 63-70.

[15] V.S. Nambiar, R. Mehta, M. Daniel, Polyphenol content of three Indian green leafy vegetables, Journal of Food Science and Technology. 42(6) (2005) 312-315.

[16] A. Yasmeen et al., Exploring the potential of Moringa oleifera leaf extract (MLE) as a seed priming agent in improving wheat performance, Turkish Journal of Botany. 37 (2013) 512520 . 
[17] J.C. Guillen-Roman et al., Effect of nitrogen privation on the phenolics contents, antioxidant and antibacterial activities in Moringa oleifera leaves, Industrial Crops \& Products. 114 (2018) 45-51.

[18] P. Siddhuraju, K. Becker, Antioxidant properties of various solvent extracts of total phenolic constituents from three different agro climatic origins of drumstick tree (Moringa oleifera Lam.) leaves, J Agric Food Chem. 51 (2003) 2144-2155.

[19] J. Barciszweski et al., Occurrence, biosynthesis and properties of kinetin (N6furfuryladenine), Plant Growth Regulation. 32 (2000) 257-265.

[20] O. Borsani, V. Valpuesta, M.A. Botella, Evidence for a role of salicylic acid in the oxidative damage generated by $\mathrm{NaCl}$ and osmotic stress in Arabidopsis seedlings, Plant Physiology. 126 (2002) 1024-1030.

[21] N. Smirnoff, G.L. Wheeler, Ascorbic acid in plants: biosynthesis and function, Critical Rev Biochem Mol Biology. 35 (2000) 291-314.

[22] P.L. Conklin, C. Barth, Ascorbic acid, a familiar small molecule interwined in the response of plants to ozone, pathogens and the onset of senescence, Plant Cell Environ. 27 (2004) 959971.

[23] I. Slesak et al., The role of hydrogen peroxide in regulation of plant metabolism and cellular signaling in response to environmental stresses, Acta Biochem Polon 54 (2007) 39-50.

[24] Information on: http://www.moringanews.org/documents/moringawebEN.pdf

[25] D.I. Arnon, Copper Enzymes in Isolated Chloroplasts, Polyphenoloxidase in Beta Vulgaris, Plant Physiology. 24 (1949) 1-15. doi: 10.1104/pp.24.1.1

[26] E.A. Ainsworth, K.M. Gillespie, Estimation of total phenolic content and other oxidation substrates in plant tissues using Folin-Ciocalteu reagent. 2 (2007) 875-877. doi: 10.1038/nprot.2007.102

[27] R.K. Sairam, Effect of moisture stress on physiological activities of two contrasting wheat genotypes, Indian Journal of Experimental Biology. 32 (1994) 584-593.

[28] R.G.D. Steel, J.H. Torrie, D.A. Dicky, Principles and Procedures of Statistics, A biometrical approach, 3rd Ed. McGraw Hill, Inc Book Co NY (USA), pp: (1997) 352-358.

[29] R.K. Saini, I. Sivanesan, Y.S. Keum, Phytochemicals of Moringa oleifera: a review of their nutritional, therapeutic and industrial significance, Biotech 6(2) (2016) 203.

[30] A. Kumar et al., Present review on phytochemistry, neutraceutical, antimicrobial, antidiabetic, biotechnological and pharmacological characteris-tics of Moringa oleifera Linn, BMR Phytomed 2(1) (2016) 1-17.

[31] B. Doerr et al., Cultivar effect on Moringa oleifera glucosinolate content and taste: A pilot study, Ecol. Food Nutrition. 48 (2009) 100-211.

[32] L.S. Taha, H.A.A. Taie, M.M. Hussein, Antioxidant Properties, Secondary metabolites and Growth as affected by application of putrescine and moringa leaves extract on jojoba plants, $\mathrm{J}$ App Phar Science. 5(01) (2015) 30-36.

[33] W. Nouman, M.T. Siddiqui, S.M.A Basra, Moringa oleifera leaf extract: An innovative priming tool for rangeland grasses, Turkish Journal of Agriculture and Forestry 36 (2011) 6575 .

[34] D.S. Arabshahi, D.D. Vishalakshi, U. Asna, Evaluation of antioxidant activity of some plant extracts and their heat, $\mathrm{pH}$ and storage stability. Food Chemistry. 100 (2007) 1100-1105. 
[35] M.A. Iqbal, Role of Moringa, Brassica and Sorghum Water Extracts in Increasing Crops Growth and Yield: A Review, American-Eurasian J Agric \& Environ Science. 14(11) (2014) 1150-1158.

[36] S. Khan et al., Growth promoting potential of fresh and stored Moringa oleifera leaf extracts in improving seedling vigor, growth and productivity of wheat crop, Environ Sci Pollution Research. 24(35) (2017) 27601-27612. doi: 10.1007/s11356-017-0336-0

[37] M.M. Abdalla, The potential of Moringa oleifera extract as a biostimulant in enhancing the growth, biochemical and hormonal contents in rocket (Eruca vesicaria subsp. sativa) plants, Int J Plant Physiol Biochemistry. 5(3) 2013) 42-49.

[38] S.M. Howladar, A novel Moringa oleifera leaf extract can mitigate the stress effects of salinity and cadmium in bean (Phaseolus vulgaris L.) plants, Ecotoxicol Environ Saf 100 (2014) 69-75.

[39] M. Prabhu, A.R. Kumar, K. Rajamani, Influence of different organic substances on growth and herb yield of sacred basil (Ocimum sanctum L), Ind J Agric Research. 44(1) (2010) 4852.

[40] R. Balakumbahan, K. Rajamani, Effects of biostimulants on growth and yield of Senna (Cassia angustifolia var KKM1), J Hort Sci Ornam Plants 2(1) (2010) 16-18. 